\title{
EXPERIMENTAL STUDY OF THE OUT OF PLANE BEHAVIOR OF MASONRY INFILL WALLS WITH EXTERIOR INSULATION SYSTEMS
}

\author{
${ }^{1}$ Cristian PETRUŞ, ${ }^{2}$ Valeriu STOIAN, ${ }^{3}$ Marius MOŞOARCĂ, \\ ${ }^{4}$ Anthimos ANASTASIADIS
}

\author{
${ }^{1,2}$ Department of Civil Engineering and Installations, Faculty of Civil Engineering \\ Politehnica University of Timișoara, no. 2A Traian Lalescu street Timişoara, Romania \\ e-mail: ${ }^{1}$ cristian.petrus@student.upt.ro, ${ }^{2}$ valeriu.stoian@.upt.ro \\ ${ }^{3}$ Department of Architecture, Faculty of Architecture and Urban Planning \\ Politehnica University of Timişoara, no. 2A Traian Lalescu street Timişoara, Romania \\ e-mail: marius.mosoarca@.upt.ro \\ ${ }^{4}$ Geostatic Ltd, No. 10 Papageorgiou street Thessaloniki, Greece \\ e-mail: anastasiadis@geostatic.eu
}

Received 8 March 2016; accepted 3 September 2016

\begin{abstract}
The objective of this study is to evaluate the out of plane behavior of a masonry infill wall provided with an exterior thermal insulation system. For this purpose there were constructed two 1:1 scale specimens of masonry infill walls in order to compare a simple wall with one having already applied an exterior thermal insulation system composed by a polystyrene insulation and a protection layer of plaster and a glass fiber mesh. The load was applied through a horizontal force, acting at the mid height of the wall. Both specimens were tested in displacement control, using alternate force with 3 cycles per loading step. As it was expected, an increased stiffness and out of plane resistance was observed for the wall provided with the insulation system. Various observations were noticed related to the technology and overall behavior of the infill masonry wall.
\end{abstract}

Keywords: Masonry infill, Out of plane behavior, thermal insulation system, glass fiber mesh

\section{Introduction}

Masonry walls used as compartment, veneer and enclosure systems in framed structures represents a current trend, evolved from the traditional building techniques based on bearing walls as structural elements. A healthy indoor environment is provided if certain rules regarding temperature, fire, durability, acoustic insulation and other factors are respected. Systems, which use masonry infill walls usually and easily, respect those requirements. The beginning of the $\mathrm{XX}^{\text {th }}$ century came with a rapid development of the reinforced concrete sector, which in turn had an effect on the masonry industry. Formerly used as bearing elements, the masonry walls present in 
reinforced concrete frame buildings were transformed into elements of negligible volume, mass and stiffness. Being constructed after the erection of the structural frame, the infill walls are currently considered in design as non-structural elements and are calculated only as a uniform vertical load on the structure, as it can see in Fig. 1. New construction techniques revealed a series of structural deficiencies related to the structural behavior of these walls. Design codes do not provide clear solutions for problems related to performance, safety, aesthetics and design. The drawbacks of design codes are more evident in case of accidental loadings (e.g. earthquakes, strong winds, settlements etc.), when these non-structural infill walls performed in a structural manner. Masonry infill walls constitutes the subject of a European research program (INSYSME), which studies innovative systems of earthquake resistant masonry enclosures in reinforced concrete buildings [1] and tries to improve current guidelines and design codes. The behavior of infill walls subjected to combined in-plane and out-ofplane actions can lead to brittle failure modes, which can affect the economy and ultimately human life. Using non-destructive tests, the evaluation of parameters used in structural analysis of masonry structures is possible [2]. Extensive research is carried out in the direction of improving the behavior of walls and the development of new materials and construction techniques which should resist exterior actions [3]-[5].
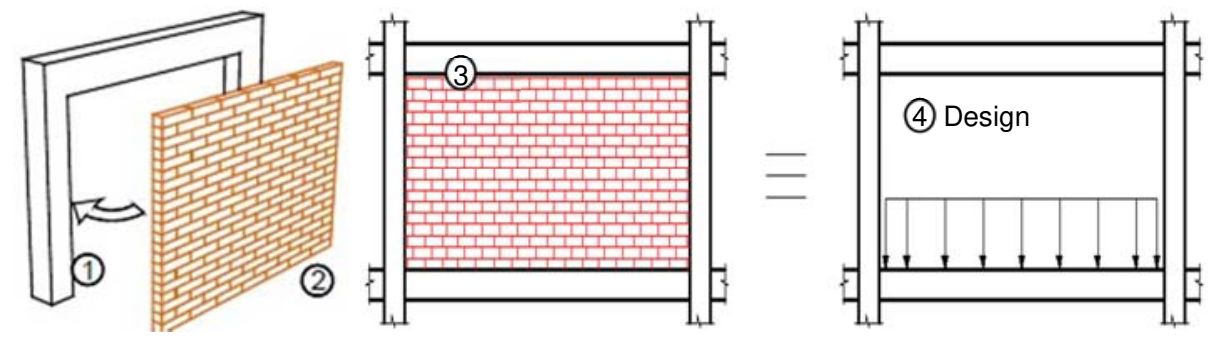

Fig. 1. Construction sequence of masonry infill walls

\section{Typical damages recorded in infill walls after earthquakes}

Having a nature difficult to predict, earthquakes affect everyday activities and all man-made constructions. The masonry infill panels from reinforced concrete frame buildings are prone to in-plane and out of plane damages. Consequently, these damages can cause the loss of building functionality, impacting everyday life at an economic and social level. Current design codes fail to provide proper regulations for these infill walls and can ultimately cause the loss of human life [6]. In order to increase the stiffness of reinforced concrete frame structures, masonry walls are introduced between the frame elements. Combining materials with different mechanical characteristics can cause an unpredictable behavior of the overall structure [7]. From this association of materials, the following scenarios can emerge: strong frame and weak infill, weak frame and strong infill, strong frame and strong infill, and weak frame with weak infill. Given the existing recordings in literature, this paper focuses on the first two scenarios. The result of the first scenario can be observed in Fig. $2 a$ as diagonal cracking of the infill panels, 
and for the second scenario Fig. $2 b$ illustrates the failure of the reinforced concrete column, as well as severe cracking of the infill wall. Overturning of the masonry infill represents the most dangerous out of plane failure. Due to the high seismic forces occurring in the non-structural elements, the masonry infill can fail out of plane, as it can be seen in Fig. $3 a$ and Fig. 3c, highlighting poor conformation to the structural frames [8]. Driven by the desire to ensure a good correction of thermal bridges in a building, veneer walls were placed over the reinforced concrete frame structure [9]. As a result of the seismic action and poor connection to the frame, failure of this veneer can be seen in Fig. $3 b$.

a)
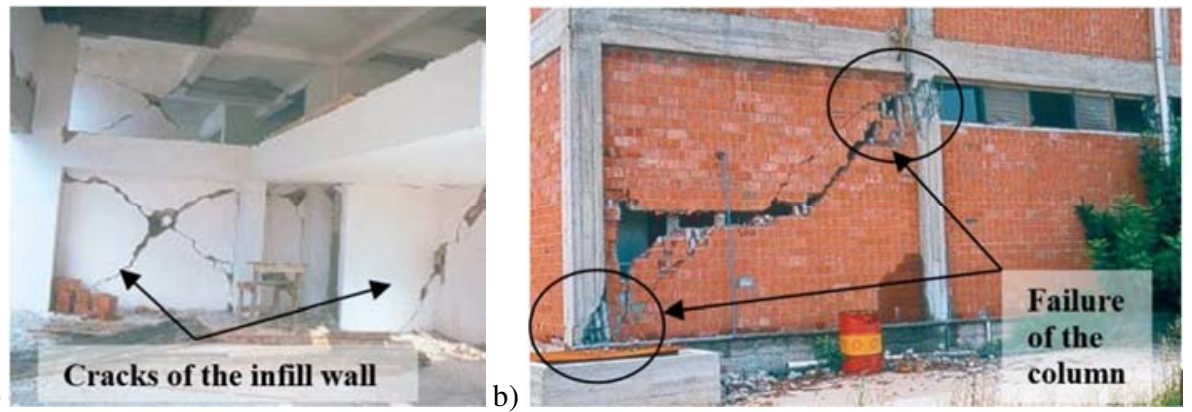

Fig. 2. In-plane damages, a) Cracking of the infill wall, Izmit earthquake; b) Local failure of reinforced concrete column, Adana-Ceyhan earthquake (after Bachmann 2002)
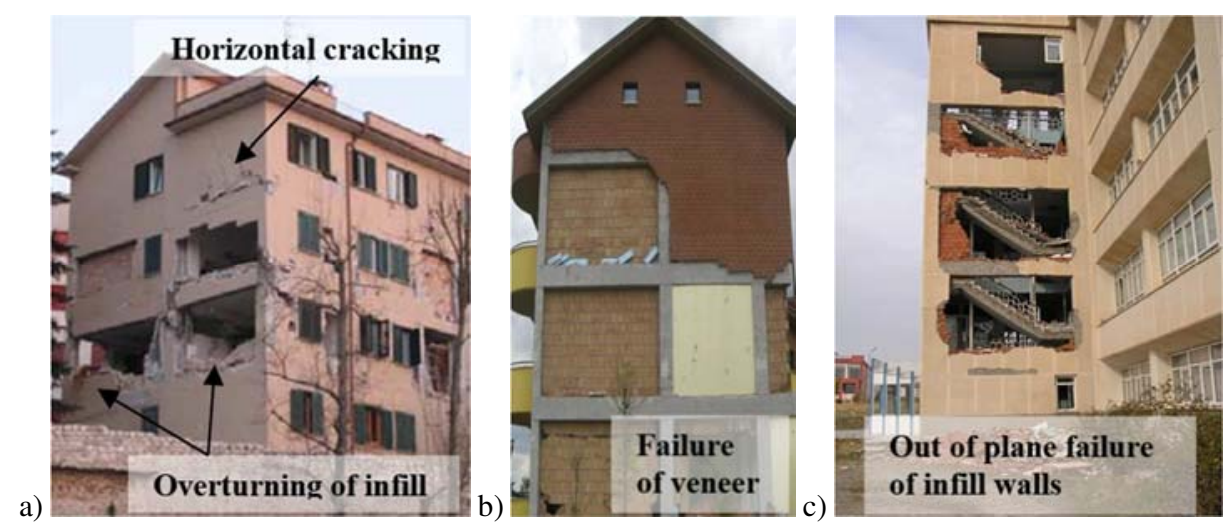

Fig. 3. Out of plane overturning of masonry infill, a) Abruzzo earthquake (after Morandi et al. 2013); b) Failure of veneer, Abruzzo (after Vicente et al. 2010); c) Van earthquake [10]

\section{Out-of-plane behavior of masonry infill}

Recordings after seismic activities indicated that the masonry infill have an inadequate serviceability performance. Failure of these walls can affect the overall behavior of a building, which can ultimately lead to its collapse. Without detailing 
provisions given in design codes, and together with poor workmanship, the resistance of these walls is reduced when subjected to out of plane loads. The Romanian seismic design code [11] accounts the interaction of reinforced concrete frame and masonry infill, only if a set of compressed diagonals are identified in the masonry panel. Due to uncertainties from the execution phase and together with the collaboration between structural and non-structural elements make this identification difficult. Two out of plane failure modes are identified by the Romanian masonry design code [12], one parallel and one perpendicular to the mortar joint, as it can be seen in Fig. $4 a$ and Fig. $4 b$.

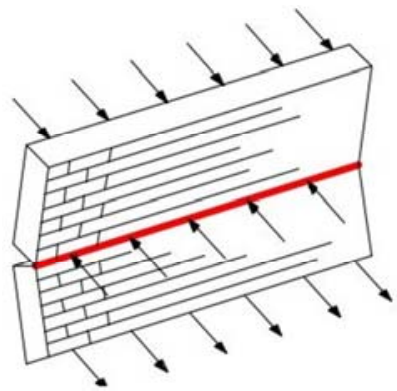

a)

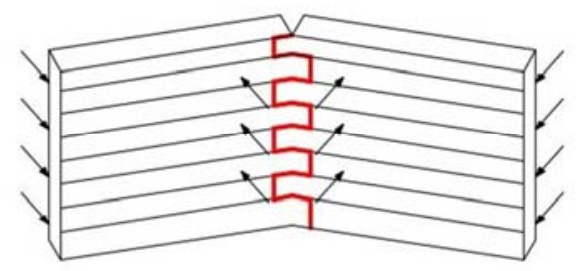

b)

Fig. 4. Out-of-plane failure modes for masonry infill walls, a) parallel with the horizontal joints; b) perpendicular on the horizontal joints

Investigation of the out of plane deformation of masonry infill is of great importance since the current design codes for seismic and masonry design do not give information regarding the performance and bearing capacities of these walls. Strategies in order to improve the behavior of these types of walls were studied, using exterior composite materials [13], or various reinforcement typologies [14]. Moreover, another interesting direction is to study measures that efficiently combine the structural rehabilitation with energetic performance of masonry infill walls [15].

\section{Experimental testing}

Two infill wall panels were constructed at a scale 1:1. The first constructed specimen (MW1) was the reference one, in order to establish a comparison. The second constructed specimen (MW2) had a $10 \mathrm{~cm}$ exterior thermal insulation system applied, composed of polystyrene panels fixed with adhesive to the infill wall surface and an exterior reinforced plaster with a glass fiber mesh. The infill panels had a dimension of $2.65 \mathrm{~m}$ width and a height of $3.50 \mathrm{~m}$. In order to construct these specimens, clay blocks with vertical holes of dimensions $375 \times 250 \times 238 \mathrm{~mm}$ (length/width/height) and a 53\% volume of holes were used together with general purpose M5 mortar. The compressive strength of a clay unit was given by the producer and had a value of $10 \mathrm{~N} / \mathrm{mm}^{2}$, while the mortar had a resistance of $5 \mathrm{~N} / \mathrm{mm}^{2}$. Material characterization tests were performed 
and reported in a design guideline for structural systems with clay blocks with vertical holes [16]. In both cases, the infill panels were simply supported on a concrete beam at the bottom side, while at the top, wooden wedges and mortar was placed between the top side of the wall and the elements of the experimental set-up, representing the current practice from Romania. No interaction was provided with the adjacent columns of the experimental stand, in order to test the infill panels only to one way vertical bending. Both wall specimens were subjected to a cyclic load applied at mid height, through a steel anchoring system composed of angle profiles and steel rods passing through the wall. A layer of rubber was placed between the angle profiles and the surface of the infill walls, in order to avoid local crushing of the masonry. The test setup of the experiment can be observed in Fig. 5. The loading protocol was performed in displacement control up to a value of $45 \mathrm{~mm}$. Three cycles were applied at each loading step in both pushing and pulling state, as it can be seen in Fig. 6 [17].

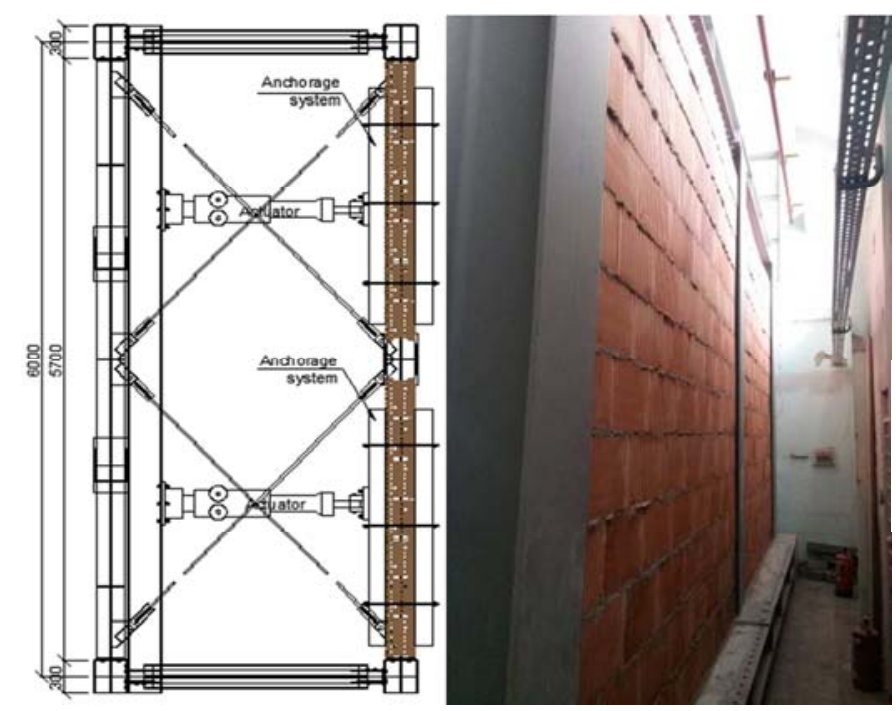

Fig. 5. Plan view of the test setup and construction stage of infill specimens
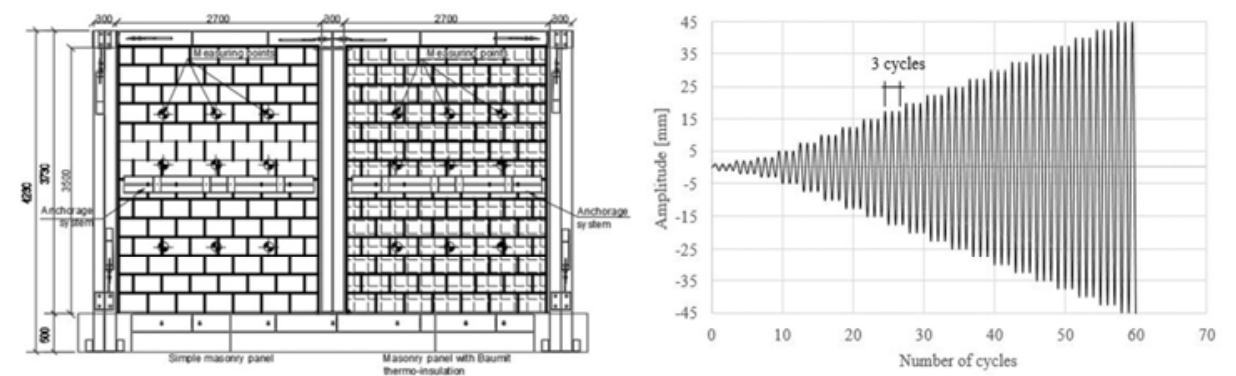

Fig. 6. Measuring points of out of plane displacement and loading protocol 
The experimental setup for infill specimen MW1 can be observed in Fig. 7. At a displacement of $10 \mathrm{~mm}$, a horizontal crack appeared in the horizontal mortar layer, followed by horizontal cracks at the bottom part and top part of the masonry wall. Increasing the displacement, the crack in the middle part of the wall opened as much as $8 \mathrm{~mm}$, as it can be seen in Fig. 8. Using a hydraulic actuator to apply pressure on the infill wall, the displacement was monitored in the central part and the force displacement curve obtained for MW1 can be observed in Fig. 9. The maximum recorded force was $56.6 \mathrm{kN}$ for an out of plane displacement at $45 \mathrm{~mm}$ representing an inter-story drift of $1.28 \%$, larger than the value of $0.7 \%$ given in the Romanian seismic codes [11]. Larger displacements were not able to be recorded due to the limitations of the laboratory equipment.
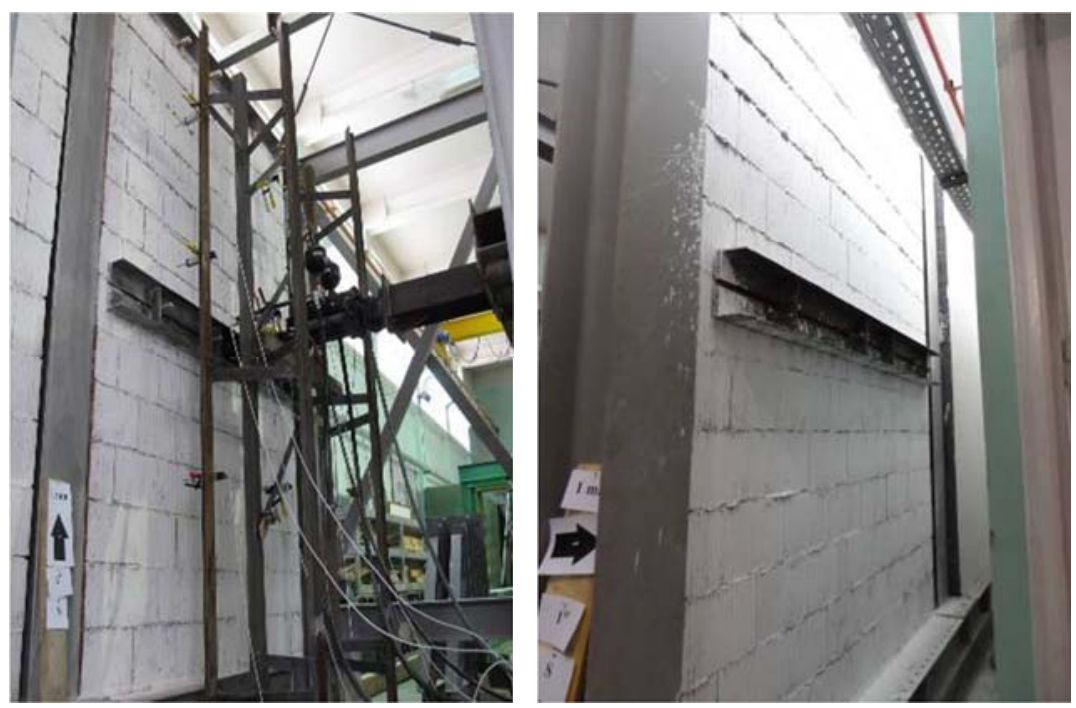

Fig. 7. Experimental setup for MW1

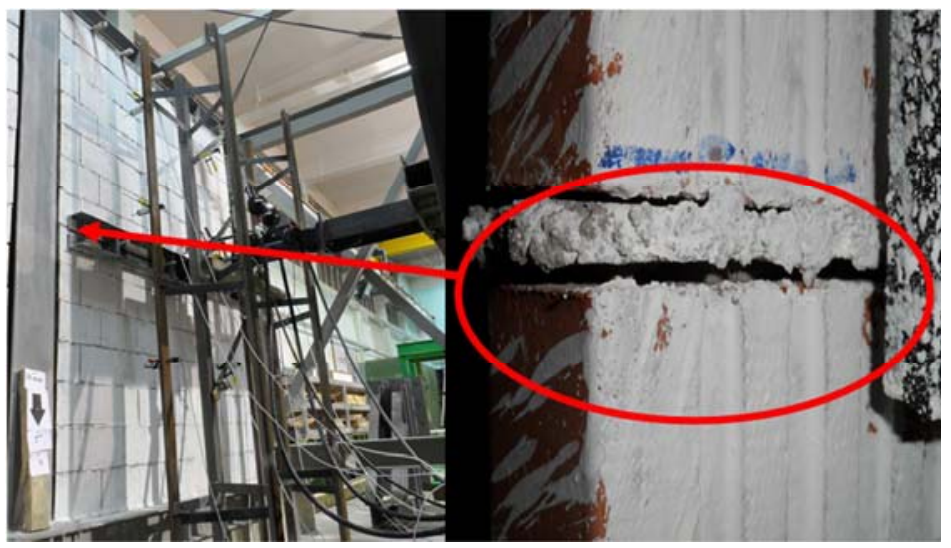

Fig. 8. Opening of horizontal crack in MW1 


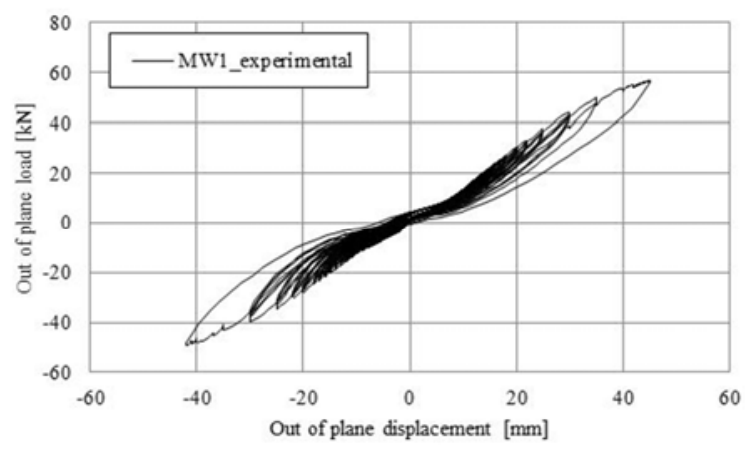

Fig. 9. Force-displacement diagram for MW1

The construction process of the infill wall specimen MW2 having a layer of thermal insulation applied can be seen in Fig. 10 and was performed as per producers requirements. The application of the insulation system on one part of the wall simulates the current trend of thermal proofing of existing and new buildings.
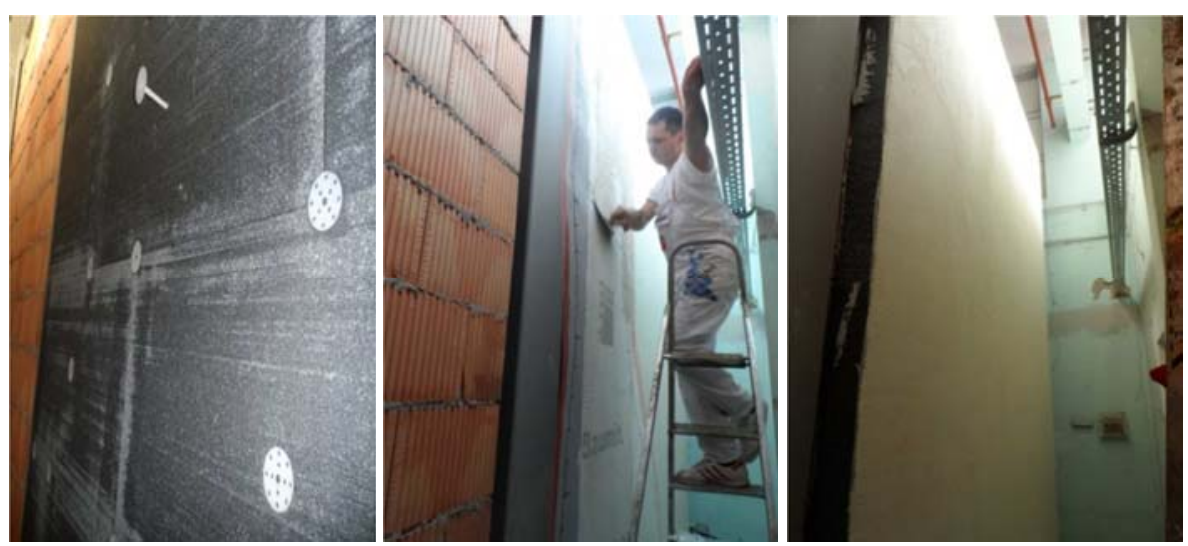

Fig. 10. Construction process of infill specimen MW2

Plastic dowels at the corners and in the middle of every polystyrene panel were provided and a reinforced plaster with glass fiber mesh was provided over the polystyrene. The tensile strength of the glass fiber mesh had a value of $1750 \mathrm{~N} / 50 \mathrm{~mm}$, as provided by the producer. An adjustment was made in order to allow for the application of the cyclic load without damaging the polystyrene, as it can be seen in Fig. 11. An overlapping of the glass fiber mesh of $40 \mathrm{~cm}$ was provided in this area.

First superficial cracks appeared in line with the steel anchoring system, as expected, at a displacement of $5 \mathrm{~mm}$, while the first crack in the horizontal joint occurred at a displacement of $7.5 \mathrm{~mm}$, as it can be seen in Fig. 12. The maximum recorded force was reached at a displacement of $42.5 \mathrm{~mm}$ and had a value of $60.44 \mathrm{kN}$, while at $45 \mathrm{~mm}$ a slight decrease of force was recorded, reaching only $58.9 \mathrm{kN}$. The force displacement 
diagram for infill wall specimen MW2 can be observed in Fig. 13. Analytical calculations performed according to Mosoarca et al. [15] can yield a good correlation with these results.

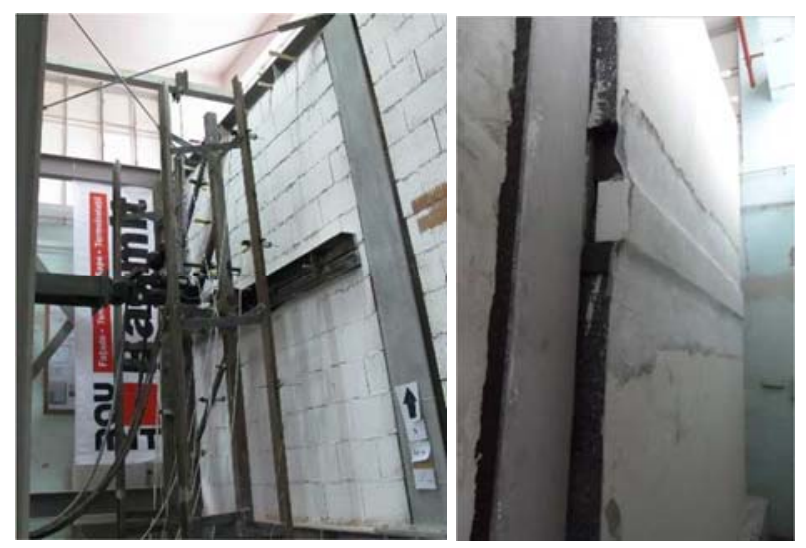

Fig. 11. Experimental setup for MW2

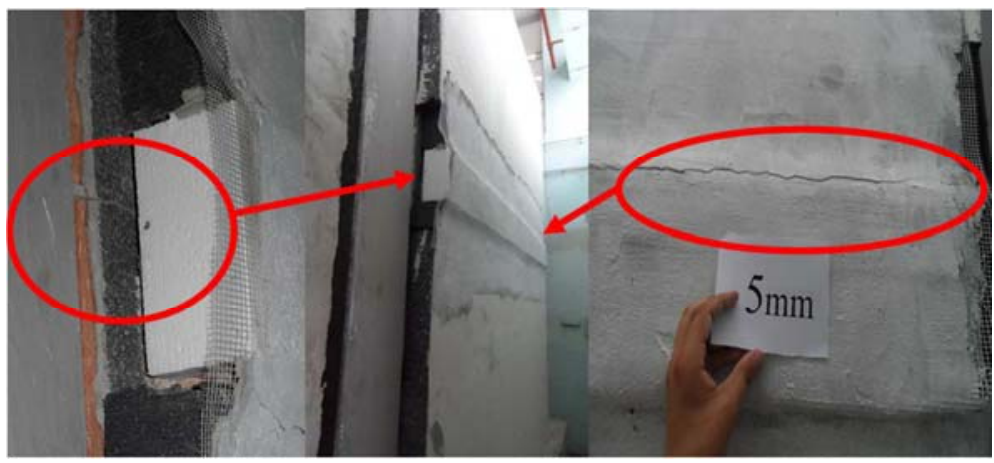

Fig. 12. Experimental setup for MW2

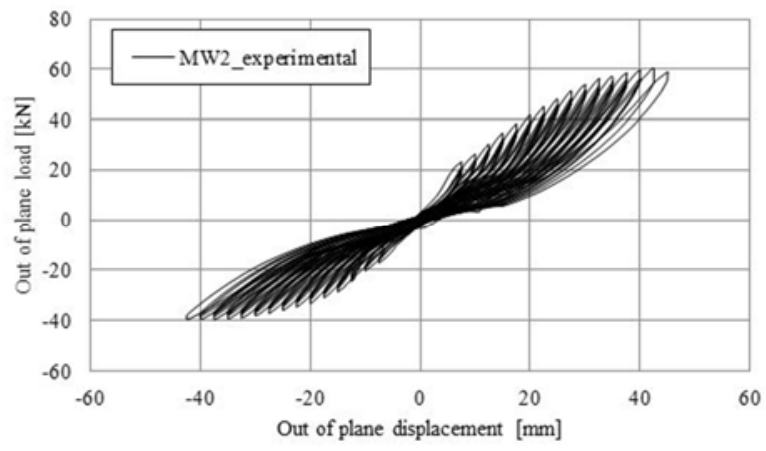

Fig. 13. Force displacement diagram for MW2 
No tearing of the glass fiber mesh was observed, although the opening of the horizontal mortar joint was about $12 \mathrm{~mm}$ at an out of plane displacement of $45 \mathrm{~mm}$. Local separation of the glass fiber mesh from the plastering was observed, in the zone adjacent to the anchoring system.

In order to better understand the effect of the thermal insulation system on the out of plane behavior of masonry infill walls, Fig. 14 presents in comparison the backbone curves of the analyzed infill specimens MW1 and MW2, in terms of resisting force and out of plane displacement. It can be seen that at the ultimate displacement of $45 \mathrm{~mm}$, the bearing capacity of MW2 had a slight increase of $6 \%$. On the other hand, an increased stiffness as well as enhanced energy dissipation can be observed for MW2, which can be translated to a better response to seismic action. Table I presents comparative values of the forces recorded at the moment in which the first crack appeared in the horizontal joint. It is clear that the external insulation system protects the infill wall confining it and providing a more stable response until the ultimate point of behavior. Fig. 15 presents the displacement measured on the height of both infill walls. It can be observed that a smaller displacement is recorded in the adjacent points of MW2.

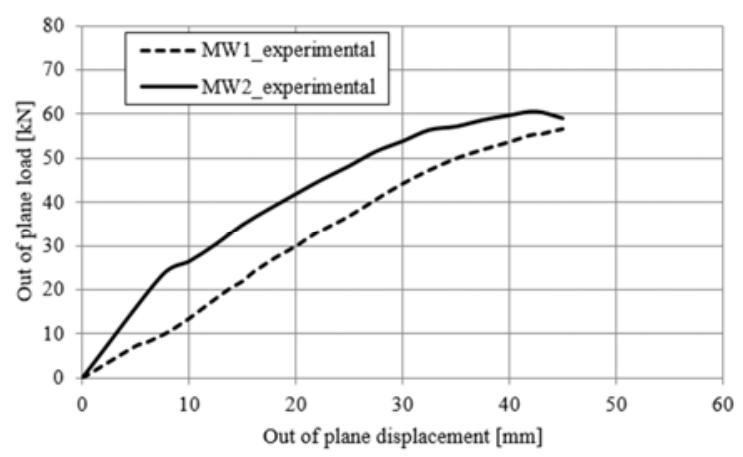

Fig. 14. Pushing state backbone curves for MW1 and MW2

Table I

Force displacement values at first horizontal crack appearance

\begin{tabular}{|c|c|c|}
\hline Infill specimen & Displacement [mm] & Force $[\mathrm{kN}]$ \\
\hline MW1 & 10 & 13.47 \\
MW2 & 7.5 & 23.29 \\
\hline
\end{tabular}

\section{Conclusions}

The experimental testing performed on masonry infill walls, revealed that the out of plane behavior of these walls is affected by placing an exterior thermal insulation system. Data obtained from testing showed an increase of $6 \%$ of the bearing capacity of these walls when subjected to cyclic loading. However, the stiffness and the overall inelastic behavior are remarkably better than the wall without the thermal insulation (MW1), due to the presence of the plaster reinforced with a mesh of glass fiber. It 
should be noticed that in these types of systems the stiffness is more important than the strength, because the infill contributes in the elastic range stiffening the reinforced concrete frame, while in a further step will absorb more energy, offering more protection to the adjacent frame. Using consolidating materials placed only on one side of the walls can be considered a viable solution for increasing their bearing capacity to out of plane seismic actions. The fact that the glass fiber mesh from the thermal insulation system did not reach a state of failure also demonstrates that the proposed solution can have a beneficial improvement against the out of plane behavior of masonry infill walls.
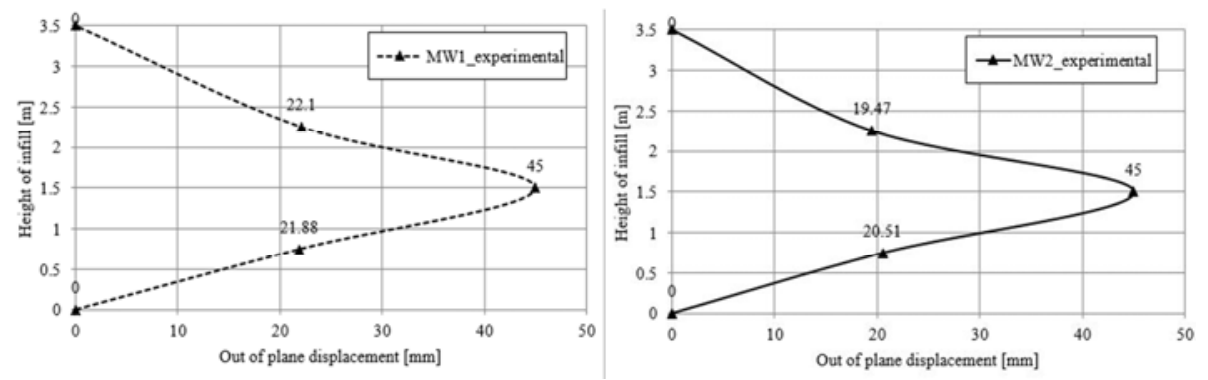

Fig. 15. Ultimate out of plane displacement for MW1 and MW2 versus the height of the infill

\section{Acknowledgements}

This project has received funding from the European Union's Seventh Programme for research, technological development and demonstration under grant agreement No 606229. Also, the authors would also like to acknowledge the support received from strategic grant POSDRU/159/1.5/S/137070 (2014) of the Ministry of National Education, Romania, co-financed by the European Social Funds - Investing in People, within the Sectorial Operational Program Human Resources Development 2007-2013. Special thanks also go to the H. I. STRUCT design office and to the Romanian representatives from Baumit and Kerakoll companies for their material and technical support.

\section{References}

[1] INSYSME, www.insysme.eu, Insysme project website, grant agreement, No. 606229 (last visited 22 January 2016).

[2] Orban Z. Increasing the reliability of the assessment of masonry arch bridges by nondestructive testing, Pollack Periodica, Vol. 1, No. 3, 2006, pp. 45-56.

[3] Fódi A., Bódi I. Comparison of shear behavior of masonry walls with and without reinforcement, Pollack Periodica, Vol. 5, No. 3, 2010, pp. 71-82.

[4] Da Porto F., Guidi N., Verlato G., Modena C. Effectiveness of plasters and textile reinforced mortars for strengthening clay masonry infill walls subjected to combined inplane/out-of-plane actions, Mauerwerk, Vol. 19, No. 5, 2015, pp. 334-354. 
[5] Valluzzi M. R., Tinazzi D., Modena C. Shear behavior of masonry panels strengthened by FRP laminates, Construction and Building Materials, Vol. 16, 2002, pp. 409-416.

[6] Braga F., Manfredi V., Masi A., Salvatori A., Vona M. Performance of non-structural elements in RC buildings during the L'Aquila, 2009 earthquake, Bulletin of Earthquake Engineering, Vol. 9, 2011, pp. 307-324.

[7] Bachmann H. Seismic conceptual design of buildings, basic principles for engineers, architects, building owners and authorities, In Swiss Federal Office for Water and Geology \& Swiss Agency for Development and Cooperation (ed.) Brotbeck Corporate Design, 2002.

[8] Morandi P., Hak S., Magenes G. Simplified out-of-plane resistance verification for slender clay masonry infill in RC frames, 15th ANIDIS Convention of Seismic Engineering, Padova, Italy, 30 June - 04 July 2013, pages 10.

[9] Vicente R., Rodrigues H., Costa A., Varum H., Mendes Da Silva J. A. R. Masonry enclosure walls, lessons learnt from the recent Abruzzo earthquake, 14th European Conference on Earthquake Engineering, Ohrid, Macedonia, 30 August - 3 September 2010, pages 8 .

[10] EERI Special Earthquake Report, Learning from Earthquakes, The Mw 7.1 Erciş-Van, Turkey Earthquake of October 23, 2011.

[11] Seismic design code, Part 1, Design provisions for buildings, indicative P100-1, (in Romanian) 2013.

[12] Design code for masonry, CR6/2013, (in Romanian) 2013.

[13] Valluzzi M. R., Da Porto F., Garbin E., Panizza M. Out-of-plane behavior of infill masonry panels strengthened with composite materials, Materials and Structures, Vol. 47, 2014, pp. 2131-2145.

[14] Baio Dias A., Da Porto F., Fehling E., Lourenco P. B., Morandi P., Vinzileou E., Yakut A. Innovative systems for earthquake resistant masonry enclosures in RC buildings, 9th International Masonry Conference, Guimarães, Portugal, 7-9 July 2014, pages ID MIE6.

[15] Mosoarca M., Petrus C., Stoian V., Anastasiadis A. Behavior of masonry infill subjected to out of plane seismic actions, Part 1, Theoretical analysis, 16th International Brick and Block Masonry Conference, Padova, Italy, June 26-30, 2016, pp. 1283-1291.

[16] Design guideline for structural systems with clay blocks with vertical holes (in Romanian), Matrix Rom, Bucharest, 2007.

[17] Mosoarca M., Petrus C., Stoian V., Anastasiadis A. Behavior of masonry infill subjected to out of plane seismic actions, Part 2, Experimental testing, 16th International Brick and Block Masonry Conference, Padova, Italy, June 26-30, 2016, pp. 1293-1299. 